\title{
EFFECTS OF INTERMITTENT HOT WATER TREATMENT ON CHERRY QUALITY
}

\author{
N. Zhang ${ }^{1 *}$, Y. Ding ${ }^{1}$, Q. Wang ${ }^{1}$ and A. Chen ${ }^{2}$ \\ ${ }^{1}$ School of Civil Engineering and Architecture, East China Jiao Tong University, Nanchang, 330013, China \\ ${ }^{2}$ Tianjin Key Laboratory of Refrigeration Technology, Tianjin University of Commerce, Tianjin, 300134, China \\ Corresponding author's email: zhangna881127@163.com
}

\begin{abstract}
In order to explore the reasons for preservation effect of hot water treatment on cherries, intermittent treatment was introduced to amplify the heat transfer factor. Cherries were immersed in hot water $\left(42^{\circ} \mathrm{C}\right)$ for $10(\mathrm{C} 1), 15 \mathrm{~min}(\mathrm{C} 2)$ continuously, or for 10 (IN1), 15 (IN2) min intermittently, respectively, and the intermittent treatment was realized through the temperature return process by room temperature water $\left(20^{\circ} \mathrm{C}\right)$ after every 5 min continuous treatment. Results showed that Group IN1, IN2 and C1 performed better than the untreated Group CK, and Group IN1 performed the best. At the fifteenth day, the weight loss ratio, browning index and respiration intensity of Group IN were $83.1 \%, 62.3 \%$ and $71 \%$ of that of Group CK, respectively, the soluble solid and titratable acid content of Group IN1 were effectively preserved, and Group IN1 also maintained good hardness, brittleness and cellular microstructure. The poor-quality and severe cell damage indicated that Group $\mathrm{C} 2$ had the worst performance and showed irreversible thermal damage. Continuously 15 min soaking in hot water exceeded the safety threshold time of treatment for the cherries, and under the same valid treatment time period, intermittent treatment showed positive performance and avoided irreversible thermal damage.
\end{abstract}

Key words: Cherry, Intermittent hot water treatment, Quality, Heat transfer characteristics.

\section{INTRODUCTION}

As a widely eaten fruit, cherries have high moisture and low calorie, and have certain preventive effects on diabetes, cardiovascular disease and cancer (Gonçalves et al., 2017). However, the fruits are highly perishable, quickly overripe and turning brown, with high postharvest losses. There are health hazards in using ordinary chemical methods to preserve fresh cherries. Therefore, it is necessary to explore safe and effective preservation methods.

Among non-chemical methods, heat treatment is a physical preservation method. Specifically, the fruits and vegetables are placed in a heat medium (hot water, hot air, hot steam) for a certain period, to achieve a certain preservation effect. This method is simple, easy to implement, and safe and efficient, it has been researched and applied on a variety of fruits and vegetables for preservation in recent years. Treating grapes with hot water at $45{ }^{\circ} \mathrm{C}$ can reduce the weight loss rate and membrane damage, and significantly inhibit the fruit chilling ( $\mathrm{Wu}$ et $a l ., 2015)$; treating apples with hot water at $50-52{ }^{\circ} \mathrm{C}$ can effectively control most rot pathogens (Di et al., 2018); heat treating ivory mangoes can inhibit respiratory rate, reduce relative conductivity and malondialdehyde content, and improve storage quality (Wang et al., 2016); heat treating peaches can also effectively alleviate browning symptoms (Huan et al., 2017). In field of heat treatment of cherries, hot air treatment can induce related cherry defense enzymes and reduce fruit morbidity (Wang et al., 2015); as for the storage quality, the weight loss rate and respiration rate of cherries can be reduced, and the solid-acid ratio can be improved without any adverse effect on taste, aroma or flavor after soaking in hot water at $40 \pm 2^{\circ} \mathrm{C}$ for 2 minutes, (Ravanfar et al., 2014); meanwhile, heat treatment is very beneficial for controlling the number of cherry codling moths and fruit browning (Feng et al., 2004).

From the perspective of heat transfer, the essence of heat treatment process is the process that heat transfers from high temperature medium to low temperature fruit and vegetable tissue. The processing temperature and processing time are two important indicators involved in the process. If the selected processing temperature and time are improper, the preservation effect will be not obvious or even irreversible thermal damage will occur. For example, if the cherries are heat treated at $48^{\circ} \mathrm{C}$ for 14 or $16 \mathrm{~min}$, pitting, depression, and severe browning may occur (Feng et al., 2004). At present, most studies intended to find more suitable combination of heat treatment temperature and time from the cherry quality or physiological indicators test. There are few studies that consider the heat transfer characteristic during the heat treatment to explore the heat transfer factors that produce different preservation effects during the heat treatment of cherries. At the same time, the existing research mostly adopts continuous heat treatment method, the treatment process doesn't change, the difference of the heat transfer process is small, and not conducive to the distinguishing of the heat transfer factors. Therefore, this paper introduces the intermittent hot water treatment method, that is, using temperature return 
treatment with room temperature water to interrupt the normal hot water treatment process to obtain differential heat transfer process, and amplify the heat transfer factor. Continuous and intermittent hot water treatment of cherries were conducted, and the internal factors of hot water treatment affecting cherry quality were explored in combination with storage quality index test, aiming to obtain better hot water treatment preservation effect.

\section{MATERIALS AND METHODS}

Plant materials: "Pioneer" cherries were purchased in Tianjin (China) Wangzhuang Market in May. Cherries similar in color and size, having no mechanical damage and being disease-free were selected and immediately shipped to the laboratory.

Treatment and storage: All the treatment and storage were carried out in the Tianjin Key Laboratory of Refrigeration Technology, and the experiment was arranged in a completely randomized design. Cherries were randomly divided into control group (CK), continuous group (C1, C2), and intermittent group (IN1, IN2). Each group had about 300 fruits. Group CK wasn't given any treatment; Group $\mathrm{C} 1$ and $\mathrm{C} 2$ were continuously soaked in hot water at $42{ }^{\circ} \mathrm{C}$ for $10 \mathrm{~min}$ and $15 \mathrm{~min}$, respectively; Group IN1 was soaked in hot water at $42{ }^{\circ} \mathrm{C}$ for $5 \mathrm{~min}$ and then soaked in water at $20^{\circ} \mathrm{C}$ for temperature return $(10$ min), and this treatment process was repeated twice; Group
IN2 was treated similar to that of Group IN1, except that the treatment process was repeated three times. At the same time, each group had 30 labeled cherries. After the treatment, the moisture on the cherry surfaces were naturally air dried, and then all cherries were transferred to the cold storage with a relative humidity of $90-95 \%$ and a temperature of $0 \pm 0.5^{\circ} \mathrm{C}$ for 12 days storage. After that, the cherries were transferred to the area with a temperature of $4 \pm 0.5^{\circ} \mathrm{C}$ for 3 days simulated shelf life. The index test was carried out every 3 days. A preliminary test had been implemented before the formal experiment.

Weight loss rate: The 30 labeled cherries from each group were weighted. The test was repeated three times for each group, and the average value was taken. The calculating formula is as follow:

$$
W=\frac{m_{f}-m_{n}}{m_{f}} * 100 \%
$$

Where, $W$ is the weight loss rate, $m_{f}$ is the initial weight of cherry and $m_{n}$ is the experimental weight of cherry.

Internal browning index: From each group, 30-40 cherries were randomly selected and were cut longitudinally. The cherries were divided into 6 grades according to the proportion of browning tissue in the longitudinal section, the details were shown in Tab.1. And the Browning index $=\Sigma$ (browning grade $\times$ number of fruits in this grade) / total number of fruits.

Table1. Classification table of internal browning index.

\begin{tabular}{lcccccc}
\hline Grade & $\mathbf{0}$ & $\mathbf{1}$ & $\mathbf{2}$ & $\mathbf{3}$ & $\mathbf{4}$ & $\mathbf{5}$ \\
\hline Percentage of Longitudinal Section Area & $0 \%$ & $1-20 \%$ & $21-25 \%$ & $26-50 \%$ & $51-75 \%$ & $76-100 \%$ \\
\hline
\end{tabular}

Respiration intensity: For respiration intensity, 30-40 cherries were randomly selected from each group and sealed in a dry container. Model GXH-3051H (Beijing, China) infrared $\mathrm{CO}_{2}$ concentration meter was used to test the $\mathrm{CO}_{2}$ concentration at the beginning and at the end of the time interval of $10 \mathrm{~min}$. The test was repeated for three times, and the average value was taken. The calculating formula is as follow:

$$
R=\frac{44 \times \Delta A \% \times V \times 273}{22.4 \times(273+\mathrm{t}) \times W \times h}
$$

Where, $R$ is the respiration intensity $(\mathrm{mg} /(\mathrm{kg} \cdot \mathrm{h})$, $\Delta A \%$ is the increasement of $\mathrm{CO}_{2}$ concentration in the dry container, $V$ is the volume of the dry container $(\mathrm{L}), \mathrm{t}$ is the tested surrounding temperature $\left({ }^{\circ} \mathrm{C}\right), W$ is the weight of cherries $(\mathrm{kg})$, and $h$ is the time duration of the respiration intensity testing $(\mathrm{h})$.

Soluble solid content (SSC) and titratable acid (TA): A portable handheld sugar meter PAL-BX\ACID1 (Japan) was used to conduct this test. The test object of each group was 30 cherries. The average value was taken as the results.
Hardness, frangibility and chewiness: The test was carried out using a texture analyzer TA-XT Plus (UK), and 30 cherries from each group were tested. Each fruit was tested for the two symmetry planes, and the results were averaged.

Cellular microstructure: Each group of cherries was sectioned and observed at the end of the experiment on the 15th day using a Model OYMPUS-CKX53 (Japan) microscope.

Heat transfer analysis: In the hot water treatment process, T type thermocouples (Tianjin, China) were used to carry out real-time monitoring of temperature inside the cherry (close to the edge of the core). The accuracy of the thermocouples was $\pm 0.1^{\circ} \mathrm{C}$. The average value of the three times tests was considered as the results.

Statistical analysis: SPSS was used to analyze experimental data. Difference significance analysis between treatment groups was performed by one-way analysis of variance (ANOVA) and treatment means were 
compared through Duncan's Multiple Range test $(\mathrm{P} \leq 0.05)$ The data were expressed as mean value \pm standard error.

\section{RESULTS AND DISCUSSION}

Weight loss ratio: As shown in Fig. 1, the weight loss ratio of each group increased with time. At the third day, there was no significant difference between each group $(P>0.05)$. At the sixth to fifteenth days, the weight loss ratio of Group IN1 and IN2 was lower than that of the other three groups, and Group IN1 had the lowest value. At the fifteenth day, Group IN1 was $81.6 \%$ and $83 \%$ of Group $\mathrm{C} 2$ and CK $(P<0.05)$, respectively; and Group IN2 was $87.2 \%$ and $89.2 \%$ of Group C2 and CK $(P<0.05)$, respectively. At the same time, the weight loss ratio of Group C1 was high, but it still showed positive effects. The effective heat treatment with suitable treatment temperature and time can inhibit the weight loss ratio, like the experimental result of sweet orange (Hussain and Rab, 2015), but when the treatment temperature is too high or the time is too long, the weight loss ratio will increase, as in the case grapes (Lydakis and Aked, 2003) and citrus (García et al., 2016), which confirmed this point of view. In this study, the result indicates the improper hot water treatment time of Group C2.

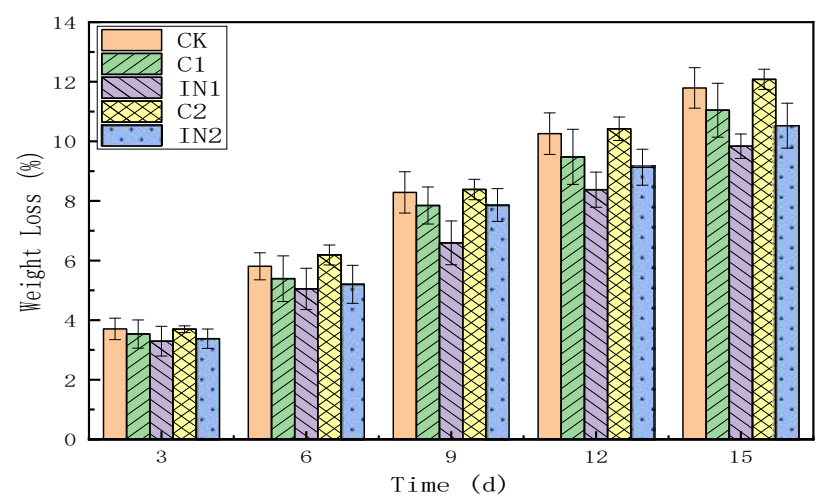

Fig. 1. Variation of the weight loss ratio for different treatment group.

Internal browning index: The browning index of fruit is an important feature to measure the quality. Fig. 2 shows that the browning index of each group increased with storage time. At the third day, browning only occurred in Group CK and $\mathrm{C} 2$, and the browning index was 0.06 and 0.17 , respectively. After the sixth day, browning occurred in all five groups, but the browning index of Group C1, IN1 and IN2 were significantly lower than that of Group CK and $\mathrm{C} 2(P<0.05)$. At the fifteenth day, the Group C2 and CK showed large-scale decay, the Group IN1 had the lowest browning index, which was $62.3 \%$ and $60 \%$ of that of Group CK and C2, respectively, and the browning index of Group IN2 and C1 was slightly higher than that of Group IN1. The results showed that effective hot water treatment can delay and inhibit the browning of cherries, and this was consistent with the results from heat treated fresh lotus roots and peaches (Li et al., 2017; Huan et al., 2017).

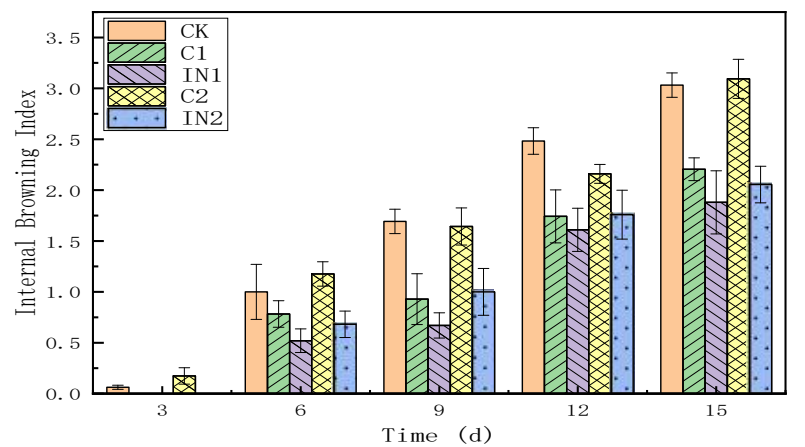

Fig. 2. Variation of browning index for different treatment group.

Respiration intensity: Cherries are typical non respiration climacteric fruits. Generally speaking, the greater the respiration intensity is, the stronger the metabolism is, and the more unfavorable of storage is. As shown in Fig. 3, the respiration intensity of the cherries in each group gradually decreased during the storage period. At the third day, the difference among each group was unobvious. At the fifteenth day, the Group $\mathrm{C} 1$ performed well ,the results showed that the appropriate hot water treatment was benefit for the storage of the cherries, and this was in agreement with the study findings of sour cherry (Ravanfar et al., 2014). And Group IN1 had the lowest respiration intensity, the respiration intensity of Group IN1 was $71 \%$ and $59 \%$ of that of Group $\mathrm{CK}$ and $\mathrm{C} 2(P \leq 0.05)$, respectively. The high respiration intensity of Group $\mathrm{C} 2$ was corresponding to the high weight loss ratio and the browning index. All these indicated that the $15 \mathrm{~min}$ continuously soaking in the hot water at $42{ }^{\circ} \mathrm{C}$ exceeded the safety threshold of hot water treatment for the cherries, and causing certain thermal damaged.

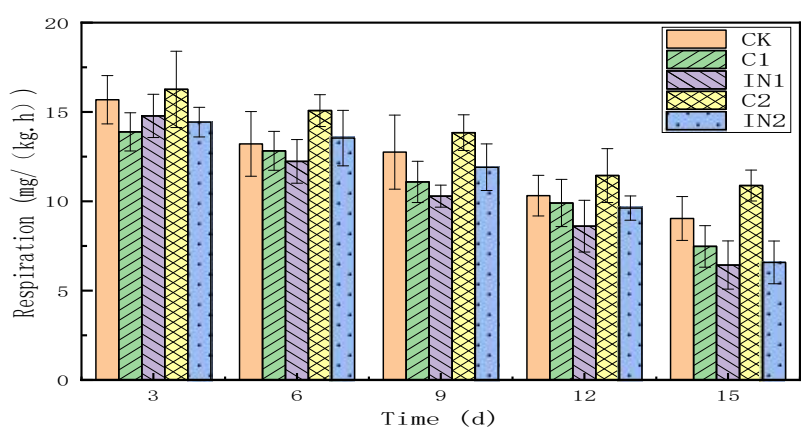

Fig. 3. Variation of respiration intensity for different treatment group.

Soluble solid content (SSC) and titratable acid (TA): As shown in Fig. 4, during the storage period, the soluble solid contents (SSC) of Group C1, IN1 and IN2 increased first 
and then decreased, and the SSC reached its highest value at the third day, that is, $16.3 \%, 16.6 \%$ and $16.1 \%$, respectively. The cherries contain organic acid such as malic acid and citric acid, and the organic acid will irreversibility convert to sugar during the heat treatment with different accumulation rate (Hui et al., 2006; Wang et al.,2013). Thus, the SSC of Group C1, IN1 and IN2 increased briefly at the third day. The trend of SSC in Group C2 was consistent with that of Group CK, and both continued to decline, which may be caused by the improper hot water treatment. At the fifteenth day, the SSC of Group C2 and CK was $11.2 \%$ and $10.3 \%$, respectively, which was significantly lower than that of the other three groups. After being treated with hot water, the reducing sugar content of the fruit increased. The higher SSC was, the higher cell osmotic pressure was, and the better water-holding capacity was. The water penetrating outwards was held back to some extent, the weight loss decrease was inhibited. This was in consistent with the variation rate of the weight loss ratio shown in Fig.1.

Fig. 4 also indicates that the titratable acid (TA) content of each group decreased with time during the storage period. At the fifteenth day, the TA of Group C1, IN1 and IN2 was $1.62 \%, 1.71 \%$ and $1.69 \%$, respectively, which was obviously higher than that of Group CK and C2 $(P<0.05)$. The ascorbic acid content of fruits and vegetables that are heat treated will rise due to the stimulation caused by the antioxidant molecular protective enzyme (Mirdehghan et al., 2006). The increased respiration intensity needed some organic acid be involved in the reactions as substrate (Klein and Lurie,1990) and this leaded to the decrease of TA value. The respiration intensity of Group C1, IN1 and IN2 was low as shown in Fig. 3, and this phenomenon was consistent with the high TA content in Fig. 4.

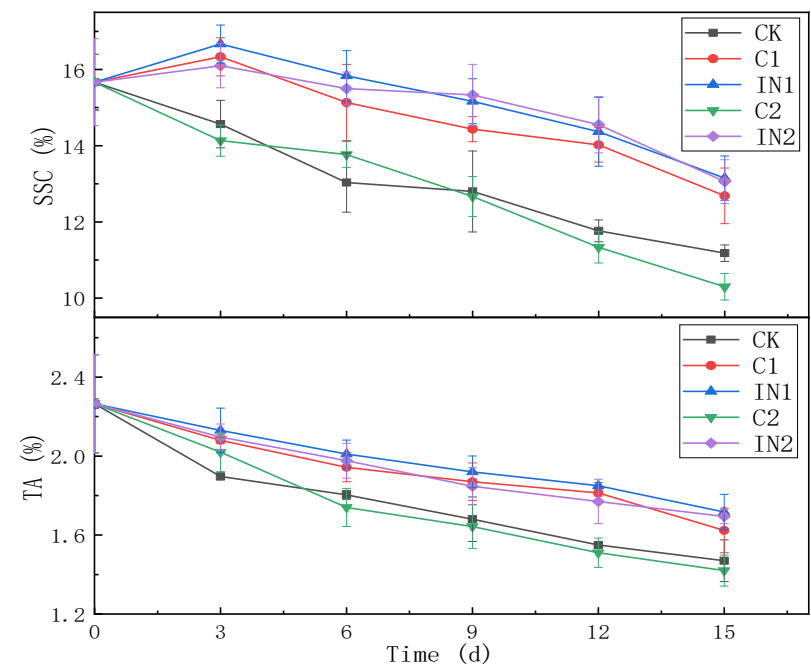

Fig. 4. Variation of SSC and TA for different treatment group.
Hardness, frangibility and chewiness: Hardness, frangibility and chewiness are important indicators for the commodity value of cherries. As indicated by Tab. 2, the hardness, frangibility and chewiness of each group declined with storage time on the whole, except that the hardness of Group C1 and IN1 at the third day and that the chewiness of Group $\mathrm{C} 1$ at the sixth day increased a little. At the sixth day, the hardness and frangibility of Group CK and $\mathrm{C} 2$ was obviously lower than that of other groups $(P<0.05)$, while the hardness of Group IN1 was the highest, about 1.36 times that of Group CK $(P<0.05)$. At the fifteenth day, Group $\mathrm{CK}$ and $\mathrm{C} 2$ showed severely softening, and their hardness, frangibility and chewiness were all low, while Group IN1 had the highest hardness, 1.89 times of that of Group CK $(P<0.05)$, and Group IN1 and IN2 showed better frangibility, 1.84 and 1.77 times of that of Group CK $(P<0.05)$,respectively. As for chewiness, Group C2 exerted worse performance, while the other groups didn't show significant difference. Compared with Group CK, Group C1, IN1 and IN2 maintained high hardness and frangibility. The softening of cherries was closely associated with the activity of pectin methylesterase, polygalacturonase and $\beta$-galactosidase (Remón et al., 2003). Pectin methylesterase can demethylate pectin to produce anionic carboxyl groups and calcium forms a salt bridge bond with the anionic carboxyl groups. According to the results, it was believed that after the hot water treatment, the enzymatic activity may cause the formation of salt bridge which enhanced the fruits' hardness.

Cellular microstructure: Observing the status of each group from a micro perspective is more intuitive. The cellular microstructure of cherries before and after the storage is given in Fig. 5. It was observed that the fresh cherries had slightly thick cell wall, integrated and full tissue, and their cell wall and cytomembrane were tightly connected and clearly visible. At the end of the storage period, the Group CK had slightly thin cell wall and large gap, the border between cell wall and cytomembrane were blurred, and the overall color was aggravated; while, the cell wall of cherries in Group C1, IN1 and IN2 maintained high integrity, and the cherry cells were neatly arranged and dense. The cellular morphology of Group IN1 were the closest to that of the fresh ones, but the color of Group IN2 was brighter than that of Group C1 and IN1. As for Group $\mathrm{C} 1$, some cell wall of cherry cells became thinner, and the color was dim. The cherries in Group C2 showed severe cellular damage.

Intermittent hot water treatment can help cherry cells keep good morphology, because using water with room temperature for temperature return treatment interrupt the thermal stress accumulation in hot water treatment process. The cell color of Group IN2 was brighter, this may be due to the reason that the hot water soaking time exceeded its safety time threshold, some 
tissue was slightly damaged, but the cytoderm integrity was high and the overall quality indexes were still good. The thermal stress of the cherries in Group C2 increased with the hot water treatment time expansion, and the cherries were subjected to severe thermal damage. These indicated that appropriate intermittent hot water treatment can produce temperature difference needed by the stress response, interrupt the continuously thermal stress accumulation in hot water treatment process and finally avoid the thermal damage. These results are consistent with that of (Zhang et al., 2014). The lower integrity of the cytomembrane is, the higher the cell function is disrupted, and the higher the risk of fruit browning is (Sun et al., 2012

; Aghdam et al., 2013). Heat treatment can regulate the fruit gene expression and the cell wall degrading enzyme activity, inhibit the cell wall degrading and slow softening (Wei et al., 2017). The cellular microstructure of cherries in Group C1, IN1 and IN2 showed high integrity, and this was closely associated with maintaining the hardness and frangibility of the cherries.

Tab.2. Variation of hardness, frangibility and chewiness for different treatment group.

\begin{tabular}{lcccccc}
\hline Time/d & $\mathbf{0}$ & $\mathbf{3}$ & $\mathbf{6}$ & $\mathbf{9}$ & $\mathbf{1 2}$ \\
\hline & & & Hardness $(\mathrm{g})$ & & \\
CK & $44.61 \pm 2.36 \mathrm{a}$ & $31.27 \pm 1.12 \mathrm{a}$ & $29.09 \pm 1.82 \mathrm{c}$ & $24.66 \pm 1.47 \mathrm{~b}$ & $19.98 \pm 1.89 \mathrm{c}$ & $14.49 \pm 2.14 \mathrm{~d}$ \\
C1 & $43.55 \pm 1.59 \mathrm{a}$ & $38.70 \pm 3.62 \mathrm{a}$ & $33.37 \pm 1.76 \mathrm{~b}$ & $29.13 \pm 0.99 \mathrm{a}$ & $27.71 \pm 1.63 \mathrm{~b}$ & $21.33 \pm 1.75 \mathrm{c}$ \\
IN1 & $44.58 \pm 2.12 \mathrm{a}$ & $41.32 \pm 4.63 \mathrm{a}$ & $39.64 \pm 1.44 \mathrm{a}$ & $34.16 \pm 0.87 \mathrm{a}$ & $30.49 \pm 1.62 \mathrm{ab}$ & $27.48 \pm 1.58 \mathrm{a}$ \\
C2 & $44.38 \pm 2.47 \mathrm{a}$ & $30.19 \pm 2.7 \mathrm{a}$ & $28.60 \pm 0.78 \mathrm{c}$ & $24.34 \pm 1.27 \mathrm{~b}$ & $21.71 \pm 1.23 \mathrm{c}$ & $11.74 \pm 1.23 \mathrm{e}$ \\
IN2 & $43.69 \pm 1.96 \mathrm{a}$ & $38.4 \pm 1.86 \mathrm{a}$ & $32.86 \pm 1.69 \mathrm{~b}$ & $28.97 \pm 1.71 \mathrm{a}$ & $28.97 \pm 2.06 \mathrm{ab}$ & $25.07 \pm 3.36 \mathrm{~b}$ \\
& & & Firmness $(\mathrm{g})$ & & \\
CK & $13.88 \pm 2.35 \mathrm{a}$ & $12.65 \pm 2.08 \mathrm{a}$ & $9.6 \pm 1.03 \mathrm{~b}$ & $8.21 \pm 1.61 \mathrm{c}$ & $7.22 \pm 1.41 \mathrm{~b}$ & $5.1 \pm 1.17 \mathrm{c}$ \\
C1 & $14.24 \pm 2.21 \mathrm{a}$ & $14.32 \pm 2.32 \mathrm{a}$ & $13.19 \pm 1.32 \mathrm{a}$ & $12.2 \pm 1.23 \mathrm{ab}$ & $10.48 \pm 2.53 \mathrm{a}$ & $6.67 \pm 1.03 \mathrm{~b}$ \\
IN1 & $14.13 \pm 1.38 \mathrm{a}$ & $14.79 \pm 4.08 \mathrm{a}$ & $13.84 \pm 1.65 \mathrm{a}$ & $13.17 \pm 2.01 \mathrm{a}$ & $11.40 \pm 3.25 \mathrm{a}$ & $9.36 \pm 2.54 \mathrm{a}$ \\
C2 & $14.64 \pm 2.54 \mathrm{a}$ & $12.64 \pm 3.52 \mathrm{a}$ & $9.63 \pm 0.97 \mathrm{~b}$ & $8.03 \pm 2.34 \mathrm{c}$ & $6.91 \pm 2.55 \mathrm{~b}$ & $5.08 \pm 2.61 \mathrm{c}$ \\
IN2 & $14.01 \pm 2.36 \mathrm{a}$ & $13.59 \pm 1.71 \mathrm{a}$ & $13.33 \pm 1.54 \mathrm{a}$ & $12.47 \pm 1.04 \mathrm{a}$ & $10.69 \pm 2.41 \mathrm{a}$ & $9.04 \pm 3.01 \mathrm{a}$ \\
& & & Chewiness $(\mathrm{g})$ & & \\
CK & $5.41 \pm 1.35 \mathrm{a}$ & $3.49 \pm 0.93 \mathrm{a}$ & $3.37 \pm 1.52 \mathrm{ab}$ & $3.00 \pm 1.19 \mathrm{~b}$ & $2.53 \pm 1.36 \mathrm{~b}$ & $1.85 \pm 0.58 \mathrm{bc}$ \\
C1 & $5.24 \pm 1.54 \mathrm{a}$ & $4.24 \pm 0.42 \mathrm{a}$ & $4.33 \pm 0.89 \mathrm{a}$ & $3.82 \pm 0.63 \mathrm{ab}$ & $3.24 \pm 1.02 \mathrm{ab}$ & $2.79 \pm 1.24 \mathrm{ab}$ \\
IN1 & $5.30 \pm 0.96 \mathrm{a}$ & $4.92 \pm 0.79 \mathrm{a}$ & $4.28 \pm 1.36 \mathrm{a}$ & $4.01 \pm 1.65 \mathrm{a}$ & $3.48 \pm 0.68 \mathrm{a}$ & $3.01 \pm 1.30 \mathrm{ab}$ \\
C2 & $5.50 \pm 1.47 \mathrm{a}$ & $3.37 \pm 1.58 \mathrm{a}$ & $3.33 \pm 0.78 \mathrm{~b}$ & $3.11 \pm 1.54 \mathrm{~b}$ & $2.37 \pm 0.86 \mathrm{~b}$ & $1.65 \pm 0.87 \mathrm{c}$ \\
IN2 & $5.37 \pm 0.67 \mathrm{a}$ & $4.64 \pm 1.79 \mathrm{a}$ & $4.16 \pm 1.64 \mathrm{a}$ & $3.85 \pm 0.98 \mathrm{ab}$ & $3.25 \pm 1.12 \mathrm{a}$ & $2.60 \pm 0.89 \mathrm{ab}$ \\
\hline
\end{tabular}

Note: the different letters $(\mathrm{a}, \mathrm{b}, \mathrm{c})$ following the average value indicates that the results have significant difference. The Duncan multiple range test $P=0.05$.
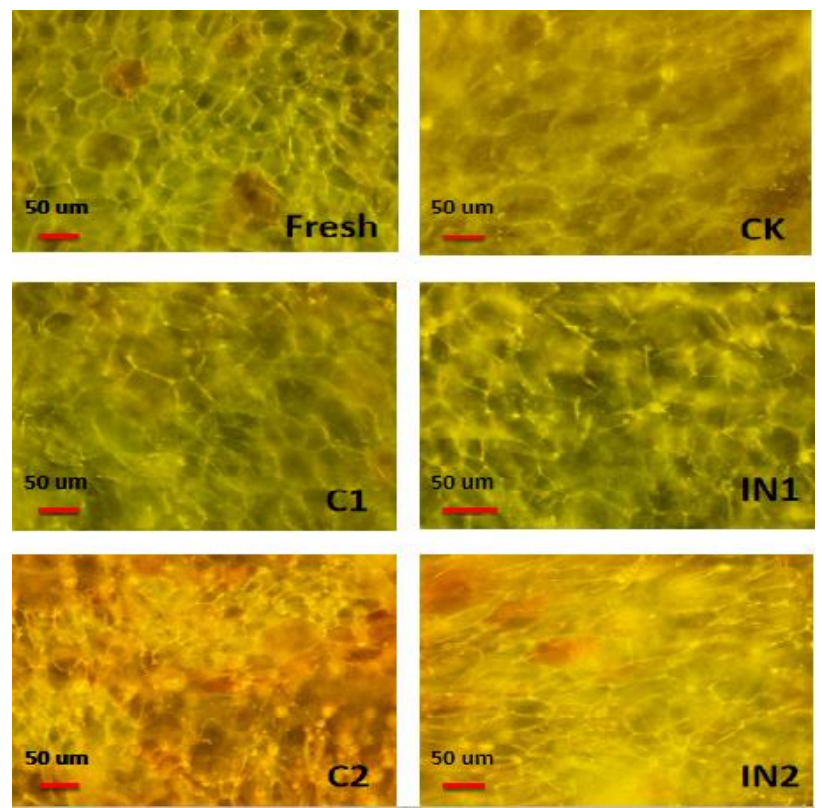

Fig. 5. Cellular microstructure for different treatment group.
Heat transfer analysis: In this study, the temperature and temperature variation rate $V$ ( change of temperature per minute ) in the cherry pulp center during the valid hot water treatment time period (the time for the cherry soaked in the hot water at $42^{\circ} \mathrm{C}$ ) were taken as the object to analysis. As shown in Fig. 6, the cherry pulp temperature in continuous Group $\mathrm{C} 1$ and $\mathrm{C} 2$ increased after the cherries being soaked in hot water at $42{ }^{\circ} \mathrm{C}$. The pulp temperature reached about $42{ }^{\circ} \mathrm{C}$ at the fifth minute. At the same time, the temperature variation rate $V$ showed different trend, it reached the maximum value $16.9{ }^{\circ} \mathrm{C} / \mathrm{min}$ at the first minute, and then decreased until to $0{ }^{\circ} \mathrm{C} / \mathrm{min}$ at the fifth minute. The intermittent group IN1 and IN2 were given temperature return treatment with water at $20{ }^{\circ} \mathrm{C}$ during the two $5 \mathrm{~min}$ hot water soaking treatment, and thus their temperature variation rate $V$ in the $10 \mathrm{~min}$ and $15 \mathrm{~min}$ valid hot water treatment period repeated that in the first 5 min continuous hot water treatment for two and three times.

As indicated by Fig. 6, based on the value of temperature and temperature variation rate $V$, the valid hot water treatment process can be divided into "heat occurrence period" in which the temperature changed 
rapidly (the first 3 minutes of the treatment, and the average temperature and $V$ were $32.4^{\circ} \mathrm{C}$ and $7.2{ }^{\circ} \mathrm{C} / \mathrm{min}$, respectively), "heat transition period" in which the temperature changed slowly (the first 3-5 minutes of the treatment, and the average temperature and $V$ were $41.7^{\circ} \mathrm{C}$ and $0.3{ }^{\circ} \mathrm{C} / \mathrm{min}$, respectively) and "heat equilibrium period" in which the temperature basically did not change (after the first 5 minutes of the treatment, and the average temperature and $V$ were $42^{\circ} \mathrm{C}$ and $0{ }^{\circ} \mathrm{C} / \mathrm{min}$, respectively). Group IN1 and IN2 belonged to the "heat occurrence period" and the "heat transition period" during the valid hot water treatment time period, while the two continuous Group C1 and C2, especially Group C2, always belonged to the "heat equilibrium period" with high tissue temperature after the first 5 minutes of treatment. According to the aforementioned indices and the cellular microstructure, Group C2 showed poor quality and its tissue cell were severely damaged. These indicated that the continuously $15 \mathrm{~min}$ soaking in hot water exceeded the safety threshold time of treatment for the cherries, and the continuously thermal stress accumulation due to the high temperature led to irreversible thermal damage to their tissue. As for the two intermittent groups, the temperature return treatment using low-temperature water helped the tissue be in the "heat occurrence period" and "heat transition period" instead of being in the "heat equilibrium period" with high temperature for a long time. It interrupted the thermal stress accumulation and avoid thermal damage, and the heat transfer due to the temperature variation may be the primary cause for good preservation effect which is induced by physiological change from hot water treatment.
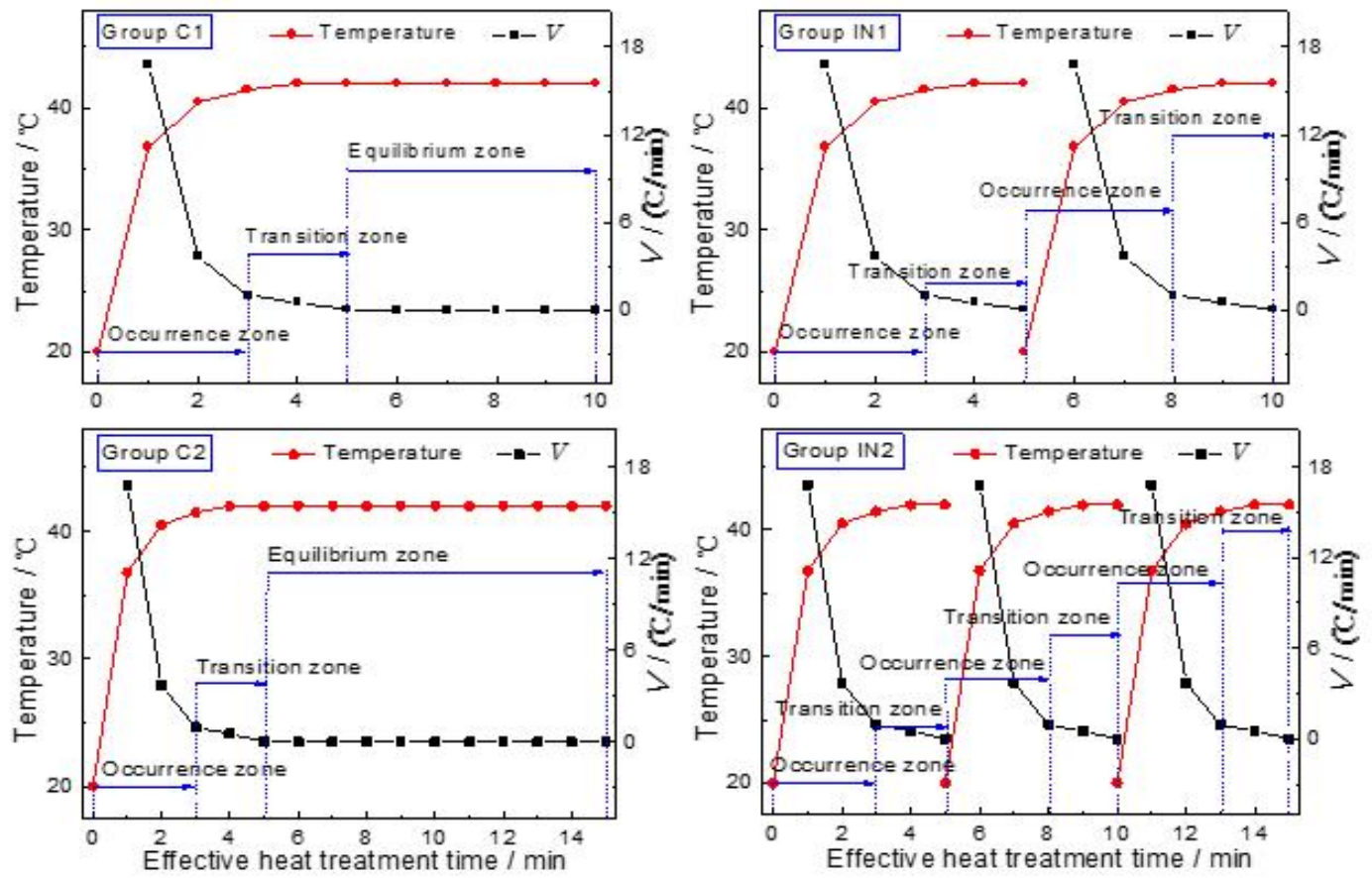

Fig. 6. Temperature and $V$ during the valid hot water treatment process for different group.

Conclusion: Compared with the control group, Group IN1, IN2 and $\mathrm{C} 1$ showed positive performance, Group IN1 performed the best, and Group $\mathrm{C} 2$ performed the worst and showed irreversible thermal damage. From the perspective of heat transfer, the good performance of intermittent group was partly due to the reason that appropriate temperature return treatment can interrupt the thermal stress accumulation and avoid thermal damage, and at the same time, the heat transfer caused by the temperature variation may be the primary reason for preservation effect of hot water treatment.

Acknowledgements: This research is supported by the Key Research and Development Projects of Jiangxi
Province (Grant No. 20181BBF68012) and Tianjin Natural Science Foundation (Grant No.18JCQNJC84600).

\section{REFERENCES}

Aghdam, M.S., L. Sevillano, F.B. Flores and S. Bodbodak (2013). Heat shock proteins as biochemical markers for postharvest chilling stress in fruits and vegetables. Sci. Hortic. 160: 54-64.

Di Francesco, A., M. Mari and R. Roberti (2018). Defense response against postharvest pathogens in hot water treated apples. Sci. Hortic. 227: 181-186.

Feng, X.Q., J.D.Hansen, B. Biasi, J.M. Tang and E. Mitcham (2004). Use of hot water treatment to 
control codling moths in harvested California 'Bing' sweet cherries. Postharvest Biol. Technol. 31(1): 41-49.

García, J.F., M. Olmo and J.M. García (2016). Decay incidence and quality of different citrus varieties after postharvest heat treatment at laboratory and industrial scale. Postharvest Biol. Technol. 118: 96-102.

Gonçalves, A.C., C. Bento, B.M. Silva and L.R. Silva (2017). Sweet cherries from Fundão possess antidiabetic potential and protect human erythrocytes against oxidative damage. Food Res. Int. 95: 91-100.

Huan, C., S. Han, L. Jiang, X.J. An, M.L. Yu, Y. Xu, R.J. Ma and Z.F. Yu (2017). Postharvest hot air and hot water treatments affect the antioxidant system in peach fruit during refrigerated storage. Postharvest Biol. Technol. 126: 1-14.

Hui, Y.H., W.K. Nip, L.M.L. Nollet, G. Paliyath and B.K. Simpson (2006). Food biochemistry and food processing. Blackwell Pub Professional; Oxford ,770p.

Hussain, I. and A. Rab (2015). Effects of low temperature storage and vapor heat treatment on the quality of sweet orange. J. Anim. Plant Sci. 25(3): 593-599.

Klein, J.D. and S. Lurie (1990). Prestorage heat treatment as a means of improving poststorage quality of apples. J. Am. Soc. Hortic. Sci. 115(2): 265-269.

Li, S.Y., X.J. Li, X. He, Z.W. Liu, Y. Yi, H.X. Wang and O. Lamikanra (2017). Effect of mild heat treatment on shelf life of fresh lotus root. LWT--Food Sci. Technol. 90: 83-89.

Lydakis, D. and J. Aked (2003). Vapour heat treatment of Sultanina table grapes. II: Effects on postharvest quality. Postharvest Biol. Technol. 27(2): 117126.

Mirdehghan, S.H., M. Rahemi, M. Serrano, F. Guillén, D. Martínez-Romero and D. Valero (2006). Prestorage heat treatment to maintain nutritive and functional properties during postharvest cold storage of pomegranate. J. Agric. Food Chem. 54(22): 8495-8500.

Ravanfar, R., M. Niakousari and N. Maftoonazad (2014). Postharvest sour cherry quality and safety maintenance by exposure to Hot-water or treatment with fresh Aloe vera gel. J. Food Sci. Technol. 51(10): 2872-2876.

Remón, S., M.E. Venturini, P. Lopez-Buesa and R. Oria (2003). Burlat cherry quality after long range transport: optimisation of packaging conditions. Innovative Food Sci. Emerging Technol. 4(4): 425-434.

Sun, J., C.B. Li, K.N. Prasad, X.G. You, L. Li, F. Liao, H.X. Peng, X.M. He, Z.C. Li and Y.Y. Zhang (2012). Membrane deterioration, enzymatic browning and oxidative stress in fresh fruits of three litchi cultivars during six-day storage. Sci. Hortic. 148: 97-103.

Wang, H., Z.W. Yang, F. Song, W.J. Chen and S.L. Zhao (2016). Effects of heat treatment on changes of respiration rate and enzyme activity of ivory mangoes during storage. J. Food Process. Preserv. 41(1): 1-8.

Wang, L., P. Jin, J. Wang, H.S. Gong, S.R. Zhang and Y.H. Zheng (2015). Hot air treatment induces resistance against blue mold decay caused by Penicillium expansum in sweet cherry (Prunus cerasus L.) fruit. Sci. Hortic. 189: 74-80.

Wang, P.F., X.F. Xue, X.P. Mu, J.C. Zhang, Q. Cao and J.J. $\mathrm{Du}$ (2013). Analysis of organic acid accumulation characteristics and organic AcidMetabolizing enzyme activities of chinese dwarf cherry (Cerasus humilis Bunge) fruit. Sci. Agric. Sin. 46(19): 4101-4109.

Wei, Y.Y., D.D. Zhou, Z.J.Wang, S.C. Tu, X.F. Shao, J. Peng, L.Q. Pan and K. Tu (2017). Hot air treatment reduces postharvest decay and delays softening of cherry tomato by regulating gene expression and activities of cell wall-degrading enzymes. J. Sci. Food Agric. 98(6): 2105-2112.

Wu, Z.M., X.Z. Yuan, H. Li, F. Liu, Y.D. Wang, J. Li, H. Cai and Y. Wang (2015). Heat acclimation reduces postharvest loss of table grapes during cold storage-Analysis of possible mechanisms involved through a proteomic approach. Postharvest Biol. Technol. 105: 26-33.

Zhang, N., Z. Yang, A.Q. Chen and S.S. Zhao (2014). Effects of intermittent heat treatment on sensory quality and antioxidant enzymes of cucumber. Sci. Hortic. 170: 39-44. 